\title{
PROBABILITAS PERUSAHAAN MANUFAKTUR YANG TERCATAT DI BURSA EFEK INDONESIA DALAM MEMBAYAR DIVIDEN
}

\author{
Rahmat Setiawan ${ }^{1 *}$, Denny Hardiko Harmasanto²
}

1,2 Fakultas Ekonomi dan Bisnis Universitas Airlangga

\section{A R T I C L E I N F O}

Article history:

Received 29 march 2019 Received in revised form 29 april 2019

Accepted 05 December 2019

Available online 11

December 2019

\section{Kata Kunci:}

Pengeluaran, Profitabilitas,

Perusahaan Manufaktur

Keywords:

Expenditure,Profitability,

Manufactur

\begin{abstract}
A B S T R A K
Penelitian ini bertujuan untuk menguji faktor-faktor yang berpengaruh pada probabilitas perusahaan manufaktur dalam membayar dividen. Variabel profitabilitas, leverage, modal kerja, cadangan kas, arus kas, aset berwujud, ukuran dan usia perusahaan serta pertumbuhan PDB dimasukkan sebagai determinan dalam kebijakan dividen perusahaan. Sampel diambil dari 112 perusahaan manufaktur yang tercatat di Bursa Efek Indonesia selama periode 2012-2018. Analisis data panel menggunakan laporan keuangan tahunan perusahaan yang diuji menggunakan logistic regression. Hasil penelitian menemukan fakta bahwa profitabilitas, cadangan kas, arus kas operasi dan ukuran perusahaan berpengaruh positif dan signifikan terhadap probabilitas perusahaan dalam membayar dividen. Sebaliknya faktor leverage, modal kerja bersih, aset berwujud dan usia perusahaan berpengaruh negatif dan signifikan
\end{abstract}

\begin{abstract}
A B S T R A C T
This study aims to examine the factors that influence the probability of manufacturing companies in dividends payout policy. Variables including profitability, leverage, working capital, cash reserves, cash flow, tangible assets, size and age of the company and GDP growth are considered as determinants in the company's dividend policy. Samples were taken from 112 manufacturing companies listed on the Indonesia Stock Exchange during the 2012-2018 period. Panel data analysis uses the company's annual financial statements which were tested using logistic regression. The results of the study found the fact that profitability, cash reserves, operating cash flow and firm size had a positive and significant effect on the probability of a company paying dividends. Conversely, leverage, net working capital, tangible assets and the age of the company have a negative and significant effect.
\end{abstract}

Copyright (c) Ekuitas: Jurnal Pendidikan Ekonomi. All rights reserved.

\section{Pendahuluan}

Di dalam perusahaan terjadi adanya pemisahan kepemilikan dan kendali. Hal ini menjadi sebab timbulnya masalah keagenen. Jensen (1976) menyatakan bahwa ada perbedaan kepentingan antara manajer dengan pemegang saham. Bukti menunjukkan bahwa manajer mengejar proyek-proyek yang tidak menguntungkan, menentang upaya pengambil-alihan dan mengejar keuntungan yang sifatnya jangka pendek. Lebih jauh Jensen berpendapat bahwa perusahaan menghasilkan kas lebih besar untuk mendanai proyekproyek yang menguntungkan. Kas ini digunakan untuk menghadapi masalah keagenan yang semakin besar karena arus kas bebas menjadi sumber konflik kepentingan pemegang saham dengan manajer. Tata kelola yang dapat mengendalikan masalah keagenan ini ditempuh perusahaan melalui mekanisme kebijakan dividen (Aguenaou et al., 2014).

Kebijakan dividen memegang peranan penting sebagai salah satu kebijakan keuangan perusahaan (Ross et al., 2013). Pembagian dividen memiliki beberapa tujuan. Tujuan pertama mengarah pada kemakmuran yang diperoleh pemegang saham. Pemegang saham yang menanamkan dananya di pasar modal menerima imbal hasil dalam bentuk dividen. Pembayaran dividen ini dapat mempengaruhi harga saham karena investor percaya

\footnotetext{
* Corresponding author.

E-mail : rahmatsetiawan@feb.unair.ac.id (Rahmat Setiawan)

$\underline{10.23887 / \text { ekuitas.v7i2.21752 }}$
} 
bahwa besarnya dividen yang dibayarkan menunjukkan prospek yang baik bagi perusahaan dimasa datang (Ozuomba et al., 2016). Dividen juga bertujuan untuk menunjukkan bahwa perusahaan memiliki kinerja yang bagus. Perusahaan yang membagikan dividen secara konsisten setiap periode bermaksud menunjukkan bahwa gejolak ekonomi yang terjadi mampu diatasi oleh perusahaan dan investor tetap memperoleh imbal hasil. Dividen juga dapat menjadi alat komunikasi manajer dan pemegang saham. Informasi kondisi internal perusahaan yang terbatas dapat diketahui investor melalui dividen seperti pertumbuhan dan prospek perusahaan (Hobbs dan Schneller, 2012).

Keputusan perusahaan mempertahankan laba untuk pertumbuhan di masa depan atau mengumumkan dividen selalu dinamis dan berusaha dijelaskan melalui teori yang berbeda. Karya teoritis dan empiris banyak dilakukan sejak lebih dari setengah abad. Berbagai teori menjelaskan perilaku dividen yang memberikan dasar literatur yang kuat untuk mengubah kebijakan dividen sesuai status keuangan perusahaan. Teori ketidakrelevanan dividen yang dicetuskan oleh Miller dan Modigliani tahun 1961 menyatakan bahwa nilai perusahaan tidak tergantung pada kebijakan dividennya (Ross et al., 2015). Kebijakan dividen bersifat residual dimana perusahaan menggunakan laba untuk membiayai investasi lebih dulu dan dividen akan dibayarkan jika ada sisa pendapatan. Teori Bird-in-the-hand (Gordon, 1963; Lintner, 1962) berpendapat bahwa pemegang saham menghindari risiko sehingga lebih memilih dividen daripada capital gain di masa depan karena pembayaran dividen dianggap lebih pasti. Teori biaya keagenan (Easterbrook, 1984) menjelaskan pentingnya dividen dalam meminimalkan biaya keagenan kepada perusahaan sehingga berkontribusi pada nilai perusahaan. Teori siklus hidup (Mueller, 1972), asimetri informasi dan teori pensinyalan (Bhattacharya, 1979) dan hipotesis arus kas bebas (Lang \& Litzenberger, 1989) mencoba menjelaskan peran faktor tingkat perusahaan dalam menentukan kebijakan dividen.

Kebijakan dividen merupakan topik yang banyak diteliti selama bertahun-tahun. Banyak faktor telah diuji untuk mengetahui apakah berpengaruh pada kecenderungan perusahaan untuk melakukan pembayaran dividen. Faktor penentu kebijakan dividen seringkali diukur melalui kecenderungan perusahaan membayar dividen atau rasio pembayaran dividen (DPR) namun seringkali hasilnya berbeda atau tidak konsisten satu sama lain. Penelitian Botoc dan Pirtea (2014) misalnya menemukan bahwa likuiditas dan profitabilitas menjadi determinan yang berpengaruh positif terhadap rasio pembayaran dividen pada perusahaan publik di Turki. Faktor lain seperti pembayaran dividen pada masa lalu juga telah diselidiki sebagai penentu kebijakan dividen. Hal ini dilakukan oleh Al-Kayed (2017) yang menemukan bahwa dividen masa lalu menjadi determinan utama yang mempengaruhi kebijakan pembayaran dividen. Al-Kayed (2017) lebih lanjut juga mengungkapkan bahwa profitabilitas, likuiditas, leverage, pertumbuhan dan dividen masa lalu di antara bank konvensional berdampak negatif pada pembayaran dividen pada perusahaan di Arab Saudi. Hasil penelitian yang berbeda ditemukan oleh Yusof dan Ismail (2016) yang menyimpulkan bahwa pembayaran dividen masa lalu tidak berpengaruh signifikan terhadap rasio pembayaran dividen pada perusahaan di Malaysia. Kebijakan dividen juga menyelidiki determinan dari kecenderungan untuk membayar dividen. Hal ini sesuai dengan pernyataan Turner et al., (2013) bahwa untuk menemukan penentu kebijakan dividen, kita tidak dapat menyelidikinya hanya dengan melihat pada satu sisi. Oleh karena itu kecenderungan perusahaan dalam membayar dividen dan tingkat pembayarannya perlu dikaji bersama dalam analisis. Pada tahap awal penelitian ini tujuan diarahkan untuk mengetahui berbagai faktor penentu kebijakan dividen. Faktor diambil dari penelitian sebelumnya yang memberikan pengaruh dominan terhadap kecenderungan untuk membayar dividen. 
Negara-negara yang penduduknya besar seperti Indonesia memiliki dasar yang kuat untuk memajukan sektor industri manufaktur karena adanya faktor economies of scale. Tahap awal pembangunan dicapai melalui penekanan pada sektor pertanian yang menjadi tumpuan hidup mayoritas penduduk. Tahap berikutnya adalah mulai berkembangnya industri manufaktur hingga kontribusinya mencapai titik optimal pada produk domestik bruto (PDB). Pengalaman mencatat bahwa negara-negara yang telah sampai pada tahap industrialisasi mencapai titik optimal saat sektor industri manufaktur dalam PDB mencapai 5 persen. Tumpuan utama pertumbuhan ekonomi Indonesia sejak tahun 2012 ditopang oleh industri manufaktur. Dari tahun 2012 sampai 2013 rata-rata pertumbuhan industri manufaktur mencapai 6,4 persen (https://kemenperin.go.id, 4 Juli 2013). Negara yang telah mencapai pendapatan per kapita dan produktivitas yang tinggi akan menuju tahap melambatnya sektor industri manufaktur dan menurunnya kontribusi dalam PDB dan mulai digantikan oleh sektor jasa.

Variabel makroekonomi seperti pertumbuhan ekonomi ini telah dicatat dalam banyak literatur memiliki pengaruh terhadap kebijakan dividen perusahaan. Penelitian Rahman dan Rashid (2009) mencatat PDB bersama faktor ekonomi makro lainnya seperti nilai tukar, suku bunga, dan tingkat inflasi dapat menyebabkan perubahan harga saham sehingga berdampak pada dividen. Kebijakan dividen merupakan cerminan dari kegiatan ekonomi. Hal ini karena dividen dibayarkan perusahaan pada akhir tahun maka perubahan indikator ekonomi makro akan mempengaruhi pembayaran dividen.

Teori-teori yang dijelaskan diatas dan bukti-bukti empiris di Indonesia selama ini masih belum memberikan kesimpulan yang konsisten. Selain itu berbagai faktor penentu kebijakan dividen yang dianalisis masih pada level perusahaan dan belum mempertimbangkan variabel ekonomi makro. Hal ini perlu dilakukan untuk mendapatkan hasil yang menyeluruh karena pengujian faktor-faktor penentu kebijakan dividen menurut Dewasiri dan Weerakoon (2016) harus diselidiki dengan melihatnya secara multi dimensi. Hal tersebut mendorong penulis melakukan penelitian tentang probabilitas perusahaan manufaktur yang tercatat di bursa efek indonesia dalam membayar dividen.

\section{Kajian Pustaka \\ Teori Dividen}

Studi sebelumnya telah menyajikan penjelasan teoritis untuk kebijakan pembayaran dividen berdasarkan faktor penentunya. Oleh karena itu perlu dipertimbangkan berbagai teori yang mendasari tentang kebijakan dividen. Teori Bird in the hand (Lintner, 1956; Gordon, 1959) menyatakan bahwa dividen yang tinggi lebih disukai oleh pemegang saham dibandingkan dengan capital gain karena diasumsikan penerimaan dividen menghasilkan imbal hasil yang lebih pasti dibandingkan imbal hasil yang diharapkan dari capital gain. Teori preferensi pajak sebaliknya menyatakan bahwa imbal hasil dari capital gain yang tinggi lebih disukai pemegang saham dibanding imbal hasil dari dividen. Hal ini disebabkan pajak atas dividen pada umumnya lebih tinggi dibandingkan dengan pajak atas capital gain (Elton dan Gruber, 1970).

Teori signaling menyatakan bahwa dividen digunakan sebagai alat menjembatani informasi profitabilitas perusahaan kepada pemegang saham eksternal karena adanya informasi asimetris (Bhattacharya, 1979). Teori biaya keagenan menyatakan bahwa dividen dapat digunakan sebagai mekanisme untuk mengurangi biaya keagenan bagi pemegang saham eksternal. Biaya keagenan menurut Easterbrook (1984) terdiri dari biaya untuk mengawasi manajer dan menghindari risiko. Biaya ini akan berkurang jika manajer dipaksa menggunakan pasar modal untuk mendapatkan sumber dana karena manajer yang diawasi 
pasar modal kemungkinan besar akan bertindak mengikuti kepentingan semua pihak (claimants).

Teori arus kas bebas yang dikemukakan Jensen (1986) mengidentifikasi arus kas bebas sebagai kelebihan arus kas yang dimiliki seorang manajer, dan menjelaskan bahwa pembayaran dividen yang mengorbankan investasi dalam proyek-proyek yang tidak menghasilkan nilai sebagai cara untuk mengurangi konflik dan biaya keagenan. Hipotesis ekstraksi sewa yang dikemukakan Shleifer dan Vishny (1997) berpendapat bahwa pemegang saham besar ingin mengambil keuntungan pribadi dari pengendalian perusahaan daripada mengharapkan dividen yang nilainya sama untuk semua pemegang saham. Teori pecking order yang dicetuskan Myers (1984) mengemukakan bahwa ketika suatu perusahaan membutuhkan dana untuk investasi maka sumber pembiayaan awal diambil dari laba ditahan kemudian sekuritas eksternal yang paling aman yaitu utang dan pilihan terakhir adalah ekuitas. Penelitian Fama dan French (2002) membuktikan pecking order terkait dengan kebijakan dividen karena perusahaan yang melakukan investasi cenderung memiliki tingkat leverage yang tinggi untuk mendanainya.

Teori efek clientele menyatakan bahwa apabila perusahaan melakukan perubahan pada kebijakan dividennya maka dapat menyebabkan kehilangan pemegang saham (klien) memiliki tujuan berbeda dari kebijakan perusahaan tersebut. Kebijakan perusahaan yang cenderung membagikan dividen akan menarik investor yang lebih suka memperoleh dividen sedangkan investor yang mengharapkan capital gain akan mengikuti perusahaan yang cenderung tidak membayar dividen (Miller dan Rock, 1985). Teori siklus hidup dividen oleh Mueller (1972) mengusulkan bahwa ketika perusahaan besar dan dewasa melakukan investasi besar, pemegang saham mungkin menghadapi pengurangan pendapatan dividen, yang memiliki implikasi besar bagi siklus hidup perusahaan. Fama dan French (2001) mengusulkan bahwa organisasi dengan laba tinggi dan prospek pertumbuhannya rendah cenderung membayar dividen, sedangkan perusahaan dengan laba rendah dan tahap pertumbuhan tinggi lebih enggan membayar dividen. De Angelo et al. (2006) menyatakan bahwa perusahaan dewasa cenderung membayar dividen, sementara perusahaan muda menolak untuk melakukannya. Teori catering dividen dikemukakan Baker dan Wurgler (2004a) berpendapat bahwa keputusan dividen dimotivasi oleh kebutuhan investor untuk saham yang membayar dividen menggunakan premi dividen. Mereka membuktikan bahwa preferensi investor berkorelasi positif dengan kecenderungan perusahaan untuk membayar dividen.

\section{Pengembangan Hipotesis}

Hipotesis pecking order dan signaling memberikan penjelasan untuk hubungan antara profitabilitas dan dividen (Yarram dan Dollery, 2015). Penelitian yang dilakukan Kuzucu (2015) mengidentifikasi bahwa faktor penentu yang berdampak negatif pada kebijakan dividen perusahaan adalah profitabilitas. Botoc dan Pirtea (2014) di sisi lain mengidentifikasi profitabilitas sebagai penentu yang berdampak positif pada kebijakan dividen. Oleh karena itu diprediksi bahwa profitabilitas memiliki dampak positif terhadap kebijakan dividen.

H1: Profitabilitas berpengaruh positif terhadap probabilitas perusahaan membayar dividen

Rozeff (1982) menunjukkan bahwa perusahaan dengan leverage yang tinggi cenderung memiliki rasio pembayaran dividen yang rendah, untuk mengurangi biaya transaksi yang terkait dengan pembiayaan eksternal. Al-Malkawi (2007) juga menunjukkan bahwa perusahaan dengan rasio utang yang tinggi cenderung membayar dividen lebih sedikit. Arko et al., (2014) mengidentifikasi leverage sebagai penentu utama kebijakan dividen perusahaan. Yusof dan Ismail (2016) mengidentifikasi utang sebagai penentu negatif 
kebijakan dividen perusahaan di Malaysia. Oleh karena itu, argumen di atas memotivasi hipotesis berikut.

H2: Leverage berpengaruh negatif terhadap probabilitas perusahaan membayar dividen

Likuiditas juga telah dipelajari sebagai penentu kebijakan dividen. Baker et al. (1985) menyatakan bahwa likuiditas merupakan penentu utama kebijakan dividen. Banerjee et al. (2007) menyoroti hubungan negatif antara kebijakan dividen dan likuiditas dan menyebutnya "hipotesis likuiditas dividen," model yang didukung oleh Zhiqiang et al. (2015). Baker dan Kapoor (2015) juga mengungkapkan dukungan kuat untuk hipotesis likuiditas dalam konteks India untuk dividen saham.

H3: Modal kerja bersih berpengaruh negatif terhadap probabilitas perusahaan membayar dividen

Perusahaan dengan ketersediaan kas yang lebih besar lebih mampu membayar dividen daripada perusahaan dengan uang tunai yang tidak mencukupi. Oleh karena itu, aset likuid menandakan kemampuan perusahaan untuk membayar dividen tanpa perlu menggunakan sumber eksternal, seperti menerbitkan utang (Al-Najjar dan Belghitar, 2011) H4: Cadangan kas berpengaruh positif terhadap probabilitas perusahaan membayar dividen

Thanatawee, (2011) berpendapat bahwa arus kas lebih penting dalam menentukan kemampuan perusahaan untuk membayar dividen adalah dibanding laba bersih. Arus kas dianggap sebagai ukuran yang relevan dari disposable income perusahaan. Mistry (2011) menemukan bahwa arus kas berhubungan positif dengan dividen karena banyaknya kas dari kegiatan operasi menunjukkan perusahaan mampu untuk membayar dividen. Oleh karena itu faktor ini diprediksi memiliki pengaruh positif dengan pembayaran dividen.

H5: Arus kas berpengaruh positif terhadap probabilitas perusahaan membayar dividen

Aivazian et al. (2003) berpandangan bahwa perusahaan menghadapi banyak kendala keuangan di pasar negara berkembang karena sumber dananya mengandalkan pembiayaan bank jangka pendek. Oleh karena itu mereka menumpuk banyak aset berwujud dan konsekuensinya membagikan dividen lebih sedikit. Perusahaan dengan aset berwujud yang tinggi ini memiliki lebih sedikit aset jangka pendek yang dapat digunakan sebagai jaminan untuk memperoleh pembiayaan. Al-Ajmi dan Abo Hussain (2011) menemukan bahwa pinjaman dari bank memainkan peran penting dalam pembiayaan perusahaan di Arab Saudi karena pasar utang kurang aktif. Fakta diatas menyiratkan ada hubungan negatif antara dividen dan aset berwujud.

H6: Aset berwujud berpengaruh negatif terhadap probabilitas perusahaan membayar dividen

Struktur kepemilikan yang tersebar di perusahaan besar menurut teori biaya keagenan akan mengurangi kemampuan investor mengelola aktivitas pendanaan sehingga menghasilkan informasi asimetris dan biaya keagenan yang tinggi. Al-Malkawi (2007) mengidentifikasi ukuran perusahaan sebagai faktor penentu kebijakan dividen yang signifikan. Artikis et al., (2011) sebaliknya mengidentifikasi bahwa ukuran perusahaan merupakan penentu yang berpengaruh negatif pada perusahaan di Jepang. Kuzucu (2015) dan Yusof and Ismail (2016) mengidentifikasi ukuran perusahaan sebagai penentu positif kebijakan dividen. Oleh karena itu diperkirakan ada hubungan positif antara ukuran perusahaan dan kebijakan dividen.

H7: Ukuran perusahaan berpengaruh negatif terhadap probabilitas perusahaan membayar dividen

Grullon et al. (2002) menunjukkan bahwa saat perusahaan menjadi dewasa maka akan mengalami kontraksi dalam pertumbuhannya sehingga mengakibatkan penurunan dalam pengeluaran modal. Perusahaan-perusahaan ini akibatnya memiliki arus kas bebas lebih banyak sebagai pembayaran dividen. Penelitian Brav et al. (2005) menunjukkan bahwa perusahaan yang lebih dewasa lebih cenderung membayar dividen. Di sisi lain, perusahaan 
yang lebih muda perlu menghasilkan cadangan untuk membiayai peluang pertumbuhan sehingga mengharuskan mereka untuk mempertahankan laba. Usia perusahaan digunakan sebagai proksi untuk mengukur kedewasaan perusahaan. Mengacu pada penelitian Osman dan Mohammed (2010) diharapkan ada hubungan positif antara dividen dan usia perusahaan.

H8: Usia Perusahaan berpengaruh positif terhadap probabilitas perusahaan membayar dividen

Dampak variabel makroekonomi pada kebijakan dividen telah banyak diteliti. Chen et al., (2005) membuktikan bahwa perubahan pada variabel ekonomi makro seperti tingkat bunga, tingkat inflasi, pertumbuhan PDB dan lainnya memiliki dampak besar pada pembayaran dividen. PDB, nilai tukar mata uang, tingkat bunga dan tingkat inflasi menyebabkan perubahan harga saham yang pada gilirannya berpengaruh pada pembayaran dividen. Variabel-variabel ini memiliki hubungan terbalik dengan kebijakan dividen serta nilai pemegang saham (Rahman dan Rashid, 2009). Kožul dan Mihalina (2013) menemukan bahwa pertumbuhan PDB negatif dan signifikan dengan kebijakan dividen. Penelitian Wang et al. (2010) menemukan bahwa pembayaran dividen pemegang saham mayoritas meningkat ketika pertumbuhan ekonomi menurun yang didukung oleh penelitian Ofori-Sasu et al., (2017) dimana pertumbuhan PDB meningkat seiring penurunan pembayaran dividen. H9: Pertumbuhan PDB berpengaruh positif terhadap probabilitas perusahaan membayar dividen

\section{Metode}

Sampel awal terdiri dari semua perusahaan manufaktur yang terdaftar di Bursa Efek Indonesia (BEI) dari tahun 2011 hingga 2019. Penelitian ini mengecualikan perusahaan dengan pendapatan negatif (kerugian bersih) untuk menghindari pembayaran dividen negatif. Sampel akhir terdiri dari kumpulan data panel dari 112 perusahaan yang terdaftar di BEI. Jumlah perusahaan yang memenuhi syarat untuk diteliti berjumlah 594 perusahaantahun. Dari jumlah tersebut 351 di antaranya adalah perusahaan yang membayar dividen dan 243 perusahaan tidak membayar dividen. Data keuangan berasal dari laporan keuangan tahunan perusahaan terkonsolidasi yang diperoleh dari laporan keuangan perusahaan dari tahun 2012 - 2018 dan tersedia secara online di Bursa Efek Indonesia (www.idx.co.id), sementara laporan lainnya dikumpulkan secara manual dari situs resmi perusahaan masingmasing.

Penelitian ini mengklasifikasikan kebijakan dividen sebagai variabel dependen. Kebijakan dividen diukur menggunakan variabel dummy dimana nilai dummy 1 adalah perusahaan yang membayar dividen sedangkan nilai dummy 0 adalah perusahaan yang tidak membayar dividen periode tersebut (Al-Najjar dan Kilincarslan, 2016). Variabel independen dalam penelitian ini adalah profitabilitas yang diukur dengan laba bersih terhadap total aset (Liu dan Chen, 2015). Leverage diukur dengan total liabilitas dibagi total aset sesuai pengukuran Kuzucu, (2015). Modal kerja bersih mengikuti Gill dan Biger (2013) yang didefinisikan sebagai aset lancar dikurangi liabilitas lancar dibagi total asset sebagai ukuran likuiditas.

Cadangan kas diukur dari kas dan setara kas serta sekuritas jangka pendek lainnya terhadap total aset mengikuti pengukuran Al-Najjar dan Belghitar (2011). Aset berwujud diperoleh dari rasio total aset dikurangi aset lancar dibagi dengan total aset sesuai pengukuran Javakhadze et al., (2014). Ukuran perusahaan diukur melalui nilai natural logaritma total sales (TS) sesuai penelitian Boţoc dan Pirtea (2014). Usia perusahaan diukur dengan menghitung jumlah tahun antara tanggal observasi dengan tahun saat perusahaan didirikan. 
Teknik analisis yang digunakan dalam penelitian ini adalah dengan analisis Logistic Regression. Regresi logistik menguji apakah variabel bebas yang dimasukkan kedalam model mampu memprediksi probabilitas terjadinya variabel dependen. Probabilitas dinyatakan dengan menggunakan rasio odds (Ghozali, 2013). Persamaan regresi logistik untuk sejumlah variabel bebas $(\mathrm{N})$ dinyatakan sebagai berikut:

$$
\begin{aligned}
\operatorname{Ln}\left[\left(N \mid X_{1} \ldots X_{8}\right)\right] & =\beta_{0}+\beta_{1} R O A_{i, t}+\beta_{2} L E V_{i, t}+\beta_{3} N W C_{i, t}+\beta_{4} C A S H_{i, t}+\beta_{5} O C F_{i, t}+\beta_{6} T A N G_{i, t}+\beta_{7} S I Z E_{i, t} \\
& +\beta_{8} A G E_{i, t}+\beta_{9} G D P_{i, t}+\mu_{i, t}
\end{aligned}
$$

\begin{tabular}{|c|c|c|c|}
\hline Variabel & Notasi & Pengukuran & Efek \\
\hline Dividen Paid & $\mathrm{DIV}_{\mathrm{i}, \mathrm{t}}$ & $\begin{array}{l}\text { Variabel dummy } \\
0=\text { tidak membayar dividen, } 1=\text { membayar dividen }\end{array}$ & \\
\hline Profitabilitas & $\mathrm{ROA}_{\mathrm{i}, \mathrm{t}}$ & $\frac{\text { Laba bersih }_{i, t}}{\text { Total aset }_{i, t}}$ & + \\
\hline Leverage & $\mathrm{LEV}_{\mathrm{i}, \mathrm{t}}$ & $\frac{\text { Total liabilitas }_{i, t}}{{\text { Total } \text { aset }_{i, t}}}$ & - \\
\hline Modal kerja bersih & $\mathrm{NWC}_{\mathrm{i}, \mathrm{t}}$ & $\frac{\text { Aset lancar }_{i, t}-\text { Liabilitas jangka pendek }_{i, t}}{\text { Total aset }_{i, t}}$ & - \\
\hline Cadangan kas & $\mathrm{CASH}_{\mathrm{i}, \mathrm{t}}$ & $\frac{\text { Kas dan setara kas }_{i, t}+\text { Sekuritas jangka pendek }_{i, t}}{\text { Total aset }_{i, t}}$ & + \\
\hline Arus kas operasi & $\mathrm{OCF}_{\mathrm{i}, \mathrm{t}}$ & $\frac{{\text { Operating cash } \text { flow }_{i, t}}_{\text {Total } \text { aset }_{i, t}}}{\text { Tot }}$ & + \\
\hline Aset berwujud & TANG $G_{i, t}$ & $\frac{\text { Total asset }_{i, t}-\text { Asetlancar }_{i, t}}{\text { Total asset }_{i, t}}$ & - \\
\hline Ukuran & $\mathrm{SIZE}_{\mathrm{i}, \mathrm{t}}$ & Natural $\log _{i, t}($ Total penjualan $)$ & + \\
\hline Usia & $\mathrm{AGE}_{\mathrm{i}, \mathrm{t}}$ & Natural $\log _{i, t}($ Jumlah tahun sejak IPO) & + \\
\hline Pertumbuhan PDB & $\mathrm{GDP}_{\mathrm{i}, \mathrm{t}}$ & Annual GDP growth Indonesia (\%) & - \\
\hline
\end{tabular}

Tabel 1. Definisi dan Pengukuran Variabel

Sumber: Data diolah, 2018

\section{Hasil dan Pembahasan}

Jumlah data yang diamati adalah 594 perusahaan tahun. Dalam sampel terlihat bahwa perusahaan mampu menghasilkan laba bersih rata-rata sebesar 6,5\% dengan total utang sebesar $49 \%$ dari aset yang dimilikinya. Proporsi aktiva lancar dibandingkan liabilitas jangka pendek sebesar $22 \%$ dan rata-rata menyimpan cadangan kas sebesar $10 \%$. Arus kas yang diperoleh dari operasi perusahaan berkisar $7 \%$ dari aset yang dimilikinya dimana sebesar 46\%-nya merupakan aset berwujud. Data deskripsi perusahaan yang menjadi sampel penelitian disajikan pada tabel.

Tabel 2. Statistik Deskriptif

\begin{tabular}{lrrrrr}
\hline & N & Minimum & Maximum & Mean & Std. Deviation \\
\hline DIV & 594 & 0,0 & 1,0 & 0,591 & 0,4921 \\
\hline ROA & 594 & $-0,54847$ & 0,92493 & 0,06472 & 0,1207138 \\
\hline LEV & 594 & 0,04134 & 3,02909 & 0,48911 & 0,3313023 \\
\hline NWC & 594 & $-1,00765$ & 0,81328 & 0,21916 & 0,2344889 \\
\hline CASH & 594 & 0,00042 & 0,70187 & 0,10781 & 0,1207271 \\
\hline OCF & 594 & $-0,29127$ & 0,79925 & 0,07253 & 0,1121271 \\
\hline TANG & 594 & 0,08926 & 0,98307 & 0,46277 & 0,1885012 \\
\hline SIZE & 594 & 6,82530 & 19,14370 & 14,36166 & 1,7480419 \\
\hline AGE & 594 & 0,69310 & 3,68890 & 2,72477 & 0,7331066 \\
\hline GDP & 594 & 4,87632 & 6,03005 & 5,16117 & 0,3366520 \\
\hline Sur
\end{tabular}

Sumber: Data sekunder diolah, 2019 
Tabel 3. Omnibus Tests of Model Coefficients

\begin{tabular}{lrrr}
\hline & Chi-square & df & Sig. \\
\hline Step & 318,540 & 9 & 0,000 \\
\hline Block & 318,540 & 9 & 0,000 \\
\hline Model & 318,540 & 9 & 0,000 \\
\hline
\end{tabular}

Omnibus Tes Koefisien Model menggunakan uji chi-square untuk melihat apakah ada perbedaan yang signifikan antara log-likelihoods (khususnya -2LLs) dari model dasar dan model baru. Model baru memiliki pengurangan -2LL secara signifikan dibandingkan dengan persamaan dasar sehingga menunjukkan bahwa model baru ini menjelaskan lebih banyak varian dalam hasil pengujian. Terlihat bahwa chi-square sangat signifikan (chi-square = $318,540 \mathrm{df}=9, \mathrm{p}<0.000$ ) sehingga model penelitian lebih baik secara signifikan dan dapat dilakukan analisis lebih lanjut.

Tabel 4. Hosmer and Lemeshow Test

\begin{tabular}{lccc}
\hline Step & $\begin{array}{c}-2 \text { Log } \\
\text { likelihood }\end{array}$ & $\begin{array}{c}\text { Cox \& Snell R } \\
\text { Square }\end{array}$ & $\begin{array}{c}\text { Nagelkerke R } \\
\text { Square }\end{array}$ \\
\hline 1 & $486,706^{\mathrm{a}}$ & 0,414 & 0,558 \\
\hline a. Estimation terminated at iteration number 6 \\
because parameter estimates changed by less than \\
,001.
\end{tabular}

\begin{tabular}{cccc}
\hline Step & Chi-square & df & Sig. \\
1 & 5,901 & 8 &, 658 \\
\hline
\end{tabular}

Tabel 5. Tabel Klasifikasi

\begin{tabular}{|c|c|c|c|c|}
\hline & & \multicolumn{3}{|c|}{ Predicted } \\
\hline \multirow{2}{*}{\multicolumn{2}{|c|}{ Observed }} & \multicolumn{2}{|c|}{ DIV } & \multirow{2}{*}{$\begin{array}{c}\text { Percentage } \\
\text { Correct }\end{array}$} \\
\hline & & Non Pay & Pay & \\
\hline \multirow{2}{*}{ DIV } & Non Pay & 184 & 59 & 75,7 \\
\hline & Pay & 50 & 301 & 85,8 \\
\hline \multicolumn{2}{|c|}{ Overall Percentage } & & & 81,6 \\
\hline
\end{tabular}

Ringkasan model memberikan nilai --2 Log likelihood dan pseudo-R2 sesuai dengan model penelitian yang diajukan. Nilai -2LL untuk model ini $(486,706)$ menunjukkan perbandingan dengan -2LL untuk model tanpa variabel independen.

yang memberi tahu kami bahwa ada kenaikan yang signifikan pada -2LL, yaitu bahwa model baru kami (dengan variabel penjelas) secara signifikan lebih cocok daripada model nol. Nilai R2 memberi tahu kami tentang seberapa banyak variasi dalam hasil dijelaskan oleh model (seperti dalam analisis regresi linier). Nilai Nagelkerke R2 menunjukkan bahwa model menjelaskan sekitar 55,8\% variasi dalam hasil. Uji Hosmer \& Lemeshow untuk ketepatan model (goodness of fit) menunjukkan bahwa model ini sesuai untuk data karena $p$-value $=0,658>0,05$. Tabel klasifikasi menunjukkan bahwa keakurasian prediksi berdasar perangkat variabel independen yang diajukan mencatat hasil $81,6 \%$

Tabel 6. Hasil Model Regresi Logistik

\begin{tabular}{rrrrrr}
\hline & B & S.E. & Wald & Sig. & Exp(B) \\
\hdashline ROA & 5,756 & 1,804 & 10,178 & 0,001 & 316,128 \\
\hline LEV & $-4,766$ & 1,154 & 17,057 & 0,000 & 0,009 \\
\hline NWC & $-2,241$ & 1,338 & 2,806 & 0,094 & 0,106 \\
\hline
\end{tabular}




\begin{tabular}{lrrrrr}
\hline CASH & 3,693 & 1,346 & 7,532 & 0,006 & 40,164 \\
\hline OCF & 3,800 & 1,531 & 6,160 & 0,013 & 44,684 \\
\hline TANG & $-2,378$ & 1,073 & 4,910 & 0,027 & 0,093 \\
\hline SIZE & 1,005 & 0,115 & 76,527 & 0,000 & 2,731 \\
\hline AGE & $-0,176$ & 0,152 & 1,325 & 0,250 & 0,839 \\
\hline GDP & $-0,446$ & 0,360 & 1,531 & 0,216 & 0,640 \\
\hline Constant & $-8,150$ & 2,333 & 12,204 & 0,000 & 0,000 \\
\hline
\end{tabular}

a. Variable(s) entered on step 1: ROA, LEV, NWC, CASH, OCF, TANG, SIZE, AGE, GDP

\section{Interpretasi koefisien regresi}

Tabel ini memberikan koefisien regresi (B), statistik Wald (untuk menguji signifikansi statistik) dan semua Odds Ratio (Exp (B)) yang penting untuk setiap kategori variabel. Pertama kali lihat pada hasil untuk ROA, ada efek keseluruhan yang sangat signifikan (Wald $=9,617$, $\mathrm{df}=1, \mathrm{p}<0.002$ ). Koefisien $\beta$ untuk ROA adalah positif dan signifikan, menunjukkan bahwa peningkatan ROA dikaitkan dengan peningkatan peluang membayar dividen. Kolom Exp(B) (Odds Ratio) menunjukkan bahwa semakin tinggi ROA perusahaan maka 316 kali lebih mungkin membayar dividen daripada perusahaan dengan ROA yang rendah. Pengaruh leverage adalah negatif $(-4,766)$ dan signifikan $(\mathrm{p}<0.000)$ menunjukkan bahwa perusahaan dengan tingkat leverage yang semakin tinggi lebih mungkin untuk tidak membayar dividen. Odds Ratio (OR) menunjukkan bahwa jika variabel lain dianggap konstan maka perusahaan dengan leverage yang tinggi 0,009 kali (atau 99\%) lebih mungkin untuk tidak membayar dividen.

Pengaruh modal kerja bersih adalah negatif $(-2,241)$ dan tidak signifikan $(0,094>0,05)$ menunjukkan bahwa perusahaan dengan tingkat modal kerja bersih yang semakin tinggi lebih mungkin untuk tidak membayar dividen. Odds Ratio menunjukkan bahwa jika variabel lain dianggap konstan maka perusahaan dengan tingkat modal kerja bersih yang tinggi 0,106 kali (atau 89\%) lebih mungkin untuk tidak membayar dividen. Pengaruh cadangan kas adalah positif $(3,693)$ dan signifikan $(0,006<0,05)$ menunjukkan bahwa perusahaan yang memiliki cadangan kas yang semakin tinggi lebih mungkin untuk membayar dividen. Odds Ratio menunjukkan bahwa jika variabel lain dianggap konstan maka perusahaan yang memiliki cadangan kas yang besar 40 kali lebih mungkin untuk membayar dividen. Pengaruh arus kas operasi adalah positif $(3,800)$ dan signifikan $(0,013<0,05)$ menunjukkan bahwa perusahaan yang memiliki arus kas operasi yang semakin tinggi lebih mungkin untuk membayar dividen. Odds Ratio menunjukkan bahwa jika variabel lain dianggap konstan maka mereka 45 kali lebih mungkin untuk membayar dividen.

Pengaruh aset berwujud adalah negatif $(-2,378)$ dan signifikan $(0,027<0,05)$ menunjukkan bahwa perusahaan yang memiliki aset berwujud yang besar lebih mungkin untuk tidak membayar dividen. Odds Ratio menunjukkan bahwa jika variabel lain dianggap konstan maka mereka 0,093 kali (atau 91\%) lebih mungkin untuk tidak membayar dividen. Pengaruh ukuran perusahaan adalah positif $(1,005)$ dan signifikan $(0,000<0,05)$ menunjukkan bahwa perusahaan yang berukuran semakin besar maka semakin tinggi kemungkinannya untuk membayar dividen. Odds Ratio menunjukkan bahwa jika variabel lain dianggap konstan maka mereka 2,7 kali lebih mungkin untuk membayar dividen. Pengaruh usia perusahaan adalah negatif $(-0,176)$ dan tidak signifikan $(0,250>0,05)$ menunjukkan bahwa usia perusahaan yang semakin tua sejak IPO maka semakin kecil kemungkinannya untuk membayar dividen. Odds Ratio menunjukkan bahwa jika variabel lain dianggap konstan maka mereka 0,839 kali (16\%) lebih mungkin untuk tidak membayar dividen. Pengaruh pertumbuhan GDP adalah negatif $(-0,446)$ dan tidak signifikan 
$(0,216>0,05)$ menunjukkan bahwa pertumbuhan GDP yang semakin tinggi maka semakin kecil kemungkinan perusahaan untuk membayar dividen. Odds Ratio menunjukkan bahwa jika variabel lain dianggap konstan maka mereka 2,7 kali lebih mungkin untuk membayar dividen.

\section{Profitabilitas}

Hasil penelitian menunjukkan profitabilitas berpengaruh positif dan signifikan terhadap kemungkinan perusahaan manufaktur yang terdaftar di Bursa Efek Indonesia dalam membayar dividen. Nilai $\operatorname{Exp}(\beta)$ menunjukkan bahwa setiap peningkatan ROA yang dimiliki perusahaan maka akan meningkatkan 316 kali kemungkinan membayar dividen. Hasil ini mendukung penelitian yang dilakukan Botoc dan Pirtea (2014) yang membuktikan bahwa profitabilitas adalah faktor penentu yang berdampak positif pada pembayaran dividen perusahaan. Penelitian ini juga menunjukkan berlakunya teori signaling dimana perusahaan menggunakan dividen untuk menyampaikan sinyal profitabilitas kepada pemegang saham eksternal (Bhattacharya, 1979)

\section{Leverage}

Hasil penelitian menunjukkan leverage berpengaruh negatif dan signifikan terhadap kemungkinan perusahaan manufaktur yang terdaftar di Bursa Efek Indonesia dalam membayar dividen. Nilai $\operatorname{Exp}(\beta)$ menunjukkan bahwa setiap peningkatan leverage perusahaan maka akan meningkatkan 316 kali kemungkinan membayar dividen. Hasil ini mendukung penelitian yang dilakukan Yusof dan Ismail (2016) yang membuktikan leverage sebagai penentu negatif kebijakan dividen perusahaan di Malaysia dan penelitian Fama dan French (2002) yang membuktikan pecking order terkait dengan kebijakan dividen karena perusahaan yang melakukan investasi cenderung memiliki tingkat leverage yang tinggi untuk mendanainya.

\section{Modal Kerja Bersih}

Hasil penelitian menunjukkan modal kerja bersih berpengaruh negatif dan signifikan terhadap kemungkinan perusahaan manufaktur yang terdaftar di Bursa Efek Indonesia dalam membayar dividen. Nilai $\operatorname{Exp}(\beta)$ menunjukkan bahwa setiap peningkatan modal kerja bersih perusahaan maka akan menurunkan 0,106 kemungkinan perusahaan membayar dividen atau ada peluang $89 \%$ perusahaan tidak membayar dividen. Pengaruh negatif modal kerja bersih yang merupakan ukuran likuiditas ini mendukung hasil penelitian Al-Kayed (2017) yang mengungkapkan bahwa likuiditas bank konvensional di Saudi Arabia berpengaruh negatif terhadap dividend yield.

\section{Cadangan Kas}

Hasil penelitian menunjukkan cadangan kas berpengaruh positif dan signifikan terhadap kemungkinan perusahaan manufaktur yang terdaftar di Bursa Efek Indonesia dalam membayar dividen. Nilai $\operatorname{Exp}(\beta)$ menunjukkan bahwa setiap peningkatan cadangan kas perusahaan maka akan meningkatkan 40 kali kemungkinan perusahaan untuk membayar dividen. Al-Najjar dan Belghitar (2011) menyatakan bahwa ketersediaan kas perusahaan yang lebih besar meningkatkan kemampuannya untuk membayar dividen daripada perusahaan yang tidak memiliki kas yang mencukupi.

\section{Arus Kas Operasi}


Hasil penelitian menunjukkan arus kas operasi berpengaruh positif dan signifikan terhadap kemungkinan perusahaan manufaktur yang terdaftar di Bursa Efek Indonesia dalam membayar dividen. Nilai $\operatorname{Exp}(\beta)$ menunjukkan bahwa setiap peningkatan arus kas operasi perusahaan maka akan meningkatkan 45 kali kemungkinan perusahaan untuk membayar dividen. Penelitian Hashemi \& Zadeh (2012) menyatakan bahwa perusahaan yang memiliki kas lebih sedikit berarti kemampuan membayar dividennya lebih kecil atau dapat dikatakan tergantung pada jumlah arus kas yang mencerminkan potensi perusahaan untuk pembayaran dividen,

\section{Aset Berwujud}

Hasil penelitian menunjukkan aset berwujud berpengaruh negatif dan signifikan terhadap kemungkinan perusahaan manufaktur yang terdaftar di Bursa Efek Indonesia dalam membayar dividen. Nilai $\operatorname{Exp}(\beta)$ menunjukkan bahwa setiap peningkatan aset berwujud maka akan menurunkan 0,093 kali kemungkinan perusahaan untuk membayar dividen. Aivazian et al. (2003) berpandangan bahwa jika jumlah aset berwujud yang dapat berfungsi sebagai jaminan utang semakin banyak maka jumlah aset lancar menjadi semakin berkurang. Sebagai akibatnya pembiayaan utang lebih tergantung pada laba ditahan sehingga kesempatan untuk membayar dividen menjadi semakin rendah. Hasil ini mendukung penelitian Vo dan Nguyen (2014) yang menemukan bahwa aset berwujud berpengaruh negatif terhadap kebijakan dividen.

\section{Ukuran Perusahaan}

Hasil penelitian menunjukkan ukuran perusahaan berpengaruh positif dan signifikan terhadap kemungkinan perusahaan manufaktur yang terdaftar di Bursa Efek Indonesia dalam membayar dividen. Nilai $\operatorname{Exp}(\beta)$ menunjukkan bahwa semakin besar tingkat penjualan perusahaan maka akan meningkatkan 2,7 kali kemungkinan perusahaan untuk membayar dividen. Teori agency cost menyatakan bahwa asimetri informasi pada kepemilikan yang tersebar di perusahaan besar akan meningkatkan biaya monitoring aktivitas pendanaan internal dan eksternal. Untuk memitigasi masalah itu dilakukan pendekatan melalui pembayaran dividen. Dengan kata lain, perusahaan yang lebih besar cenderung membayar dividen yang lebih tinggi daripada perusahaan yang lebih kecil. Hasil ini mendukung penelitian Kuzucu (2015), Yusof dan Ismail (2016) mengidentifikasi ukuran perusahaan sebagai penentu positif kebijakan dividen.

\section{Usia Perusahaan}

Hasil penelitian menunjukkan usia perusahaan berpengaruh negatif dan tidak signifikan terhadap kemungkinan perusahaan manufaktur yang terdaftar di Bursa Efek Indonesia dalam membayar dividen. Nilai $\operatorname{Exp}(\beta)$ menunjukkan bahwa semakin lama perusahaan masuk di pasar modal maka hanya 0,839 kali kemungkinannya untuk membayar dividen. Hasil penelitian ini mengikuti teori siklus hidup dividen oleh Mueller (1972) yang menyatakan bahwa ketika perusahaan besar dan dewasa melakukan investasi besar yang membutuhkan banyak biaya maka pembayaran dividen akan cenderung berkurang.

\section{Pertumbuhan PDB}

Hasil penelitian menunjukkan pertumbuhan PDB berpengaruh negatif dan tidak signifikan terhadap kemungkinan perusahaan manufaktur yang terdaftar di Bursa Efek Indonesia dalam membayar dividen. Nilai $\operatorname{Exp}(\beta)$ menunjukkan bahwa setiap peningkatan pertumbuhan PDB maka akan menurunkan 2,7 kali kemungkinan untuk membayar dividen. 
Hasil ini konsisten dengan penelitian Kožul dan Mihalina (2013) yang menemukan bahwa pertumbuhan PDB negatif dan signifikan dengan kebijakan dividen.

\section{Simpulan dan Saran}

Penelitian ini bertujuan untuk mengidentifikasi dan mengukur pengaruh profitabilitas, leverage, modal kerja bersih, cadangan kas, arus kas operasi, aset berwujud, ukuran dan usia perusahaan serta variabel makro yaitu pertumbuhan PDB terhadap probabilitas kebijakan pembayaran dividen pada perusahaan manufaktur di Bursa Efek Indonesia. Hasil penelitian menyimpulkan bahwa profitabilitas, cadangan kas, arus kas operasi dan ukuran perusahaan berpengaruh positif signifikan terhadap probabilitas perusahaan dalam membayar dividen bahkan probabilitas dari faktor-faktor ini mencapai lebih dari 2 kali lipat. Hal ini berarti bahwa perusahaan akan membayar dividen apabila kegiatan usahanya menghasilkan laba, kasnya memiliki cadangan yang memadai, bisnisnya menghasilkan arus kas operasi dan total penjualannya selama satu periode cukup besar. Di sisi lain, faktor leverage, modal kerja bersih, aset berwujud dan usia perusahaan berpengaruh negatif dan signifikan terhadap probabilitas perusahaan dalam membayar dividen. Faktor-faktor penentu ini dapat memberikan pertimbangan bagaimana seharusnya investor memilih perusahaan untuk menanamkan modalnya sehingga memperoleh imbal hasil dalam bentuk dividen.

Hasil penelitian ini memberikan dukungan atas teori bird in the hand (Lintner, 1956; Gordon, 1959) dimana pemegang saham lebih menyukai dividen yang tinggi karena diasumsikan penerimaan dividen memberikan imbal hasil yang lebih pasti dibandingkan capital gain. Dukungan juga diberikan pada teori signaling yang menyatakan bahwa dividen menjadi alat yang menjembatani informasi profitabilitas perusahaan kepada pemegang saham eksternal karena adanya informasi asimetris (Bhattacharya, 1979). Hasil penelitian ini juga menyimpulkan bahwa semakin besar ukuran perusahaan maka cenderung meningkatkan pembayaran dividen untuk mengurangi masalah keagenan. Penelitian ini memberikan implikasi bagi investor dan peneliti. Investor yang tertarik pada saham yang dapat memberikan dividen maka sebagai langkah awal mereka harus mempertimbangkan data profitabilitas, cadangan kas, arus kas operasi dan ukuran perusahaan yang telah membayar dividen di masa lalu karena mereka menunjukkan kecenderungan yang lebih tinggi untuk membayar dividen.

Penelitian selanjutnya perlu dilakukan dengan mempertimbangkan faktor-faktor lain yang belum dimasukkan di dalam model penelitian ini. Determinan yang perlu dimasukkan misalnya seperti pengujian oleh Dewasiri et al (2019) yang mempertimbangkan dividen masa lalu sebagai determinan utama kebijakan dividen di India. Pajak perusahaan juga disebutkan dalam teori preferensi pajak yang memperhitungkan pengaruh pajak yang menyebabkan kondisi pasar tidak sempurna (Elton dan Gruber, 1970). Literatur juga mencatat (misalnya Yarram dan Dollery, 2015) bahwa pengaruh tata kelola perusahaan mempengaruhi arah kebijakan dividen perusahaan yang perlu dimasukkan dalam penelitian berikutnya.

\section{Daftar Pustaka}

Aguenaou, S., Farooq, O. and Di, H., 2014. Dividend policy and ownership structure: evidence from the Casablanca Stock Exchange. GSTF Journal on Business Review (GBR), 2(4).

Aivazian, V., Booth, L. and Cleary, S., 2003. Do emerging market firms follow different dividend policies from US firms?. Journal of Financial research, 26(3), pp.371-387. 
Al-Najjar, B. and Belghitar, Y., 2011. Corporate cash holdings and dividend payments: Evidence from simultaneous analysis. Managerial and decision Economics, 32(4), pp.231-241.

Al-Najjar, B. and Kilincarslan, E., 2016. The effect of ownership structure on dividend policy: evidence from Turkey. Corporate Governance: The international journal of business in society, 16(1), pp.135-161.

Al-Ajmi, J. and Abo Hussain, H., 2011. Corporate dividends decisions: evidence from Saudi Arabia. The Journal of Risk Finance, 12(1), pp.41-56.

Al-Kayed, L. T. (2017). Dividend payout policy of Islamic vs conventional banks: case of Saudi Arabia. International Journal of Islamic and Middle Eastern Finance and Management, 10(1), 117-128.

Artikis, G.P., Harada, K. and Nguyen, P., 2011. Ownership concentration and dividend policy in Japan. Managerial Finance.

Baker, M. and Wurgler, J., 2004. A catering theory of dividends. The Journal of Finance, 59(3), pp.1125-1165.

Baker, H.K., Weigand, R. and Kapoor, S., 2015. Dividend policy in India: new survey evidence. Managerial Finance.

Boţoc, C. and Pirtea, M., 2014. Dividend payout-policy drivers: evidence from emerging countries. Emerging Markets Finance and Trade, 50(sup4), pp.95-112.

C. Arko, A., Abor, J., KD Adjasi, C. and Amidu, M., 2014. What influence dividend decisions of firms in Sub-Saharan African?. Journal of Accounting in Emerging Economies, 4(1), pp.57-78.

Chen, Z., Cheung, Y.L., Stouraitis, A. and Wong, A.W., 2005. Ownership concentration, firm performance, and dividend policy in Hong Kong. Pacific-Basin Finance Journal, 13(4), pp.431-449.

DeAngelo, H., DeAngelo, L. and Stulz, R.M., 2006. Dividend policy and the earned/contributed capital mix: a test of the life-cycle theory. Journal of Financial economics, 81(2), pp.227-254.

Dewasiri, N.J., Yatiwelle Koralalage, W.B., Abdul Azeez, A., Jayarathne, P.G.S.A., Kuruppuarachchi, D. and Weerasinghe, V.A., 2019. Determinants of dividend policy: evidence from an emerging and developing market. Managerial Finance, 45(3), pp.413-429.

Easterbrook, F.H., 1984. Two agency-cost explanations of dividends. The American economic review, 74(4), pp.650-659.

Elton, E.J. and Gruber, M.J., 1970. Marginal stockholder tax rates and the clientele effect. The Review of Economics and Statistics, pp.68-74.

Fama, E.F. and French, K.R., 2002. Testing trade-off and pecking order predictions about dividends and debt. The review of financial studies, 15(1), pp.1-33.

Ghozali, I., 2013. Aplikasi Analisis Multivariate dengan Program IBM SPSS 21 Update PLS. Edisi Ketujuh. Penerbit Universitas Diponegoro. Semarang.

Gill, A.S. and Biger, N., 2013. The impact of corporate governance on working capital management efficiency of American manufacturing firms. Managerial Finance, 39(2), pp.116-132.

Hashemi, S.A. and Zadeh, F.Z.F., 2012. The impact of financial leverage operating cash flow and size of company on the dividend policy (case study of Iran). Interdisciplinary Journal of Contemporary Research in Business, 3(10), pp.264-270.

Hobbs, J., \& Schneller, M. I. (2012). Dividend signalling and sustainability. Applied Financial Economics, 22(17), 1395-1408. 
Javakhadze, D., Ferris, S.P. and Sen, N., 2014. An international analysis of dividend smoothing. Journal of Corporate Finance, 29, pp.200-220.

John, S.F. and Muthusamy, K., 2010. Leverage, growth and profitability as determinants of dividend payout ratio-evidence from Indian paper industry. Asian Journal of Business Management Studies, 1(1), pp.26-30.

Kožul, A. and Mihalina, E., 2013. The determinants of the dividend size in Croatia. UTMS Journal of Economics, 4(2), pp.143-151.

Kuzucu, N., 2015. Determinants of dividend policy: a panel data analysis for turkish listed firms. International Journal of Business and Management, Forthcoming.

Liu, C. and Chen, A.S., 2015. Do firms use dividend changes to signal future profitability? A simultaneous equation analysis. International Review of Financial Analysis, 37, pp.194-207.

Miller, M.H. and Rock, K., 1985. Dividend policy under asymmetric information. The Journal of finance, 40(4), pp.1031-1051.

Mistry, D.S., 2011. Determinants of dividend payout ratio: A firm level study of major pharma players in India.

Myers, S.C., 1984. The capital structure puzzle. The journal of finance, 39(3), pp.574-592.

Ofori-Sasu, D., Abor, J.Y. and Osei, A.K., 2017. Dividend policy and shareholders' value: evidence from listed companies in Ghana. African Development Review, 29(2), pp.293304.

Osman, D. and Mohammed, E., 2010. Dividend Policy in Saudi Arabia. The International Journal of Business and Finance Research, 4(1), pp.99-113.

Ozuomba, C.N., Anichebe, A.S. and Okoye, P.V.C., 2016. The effect of dividend policies on wealth maximization-a study of some selected plcs. Cogent Business \& Management, 3(1), p.1226457.

Rashid, A. and Rahman, A.A., 2008. Dividend policy and stock price volatility: evidence from Bangladesh. The Journal of Applied Business and Economics, 8(4), p.71.

Ross, S.A., Westerfield, R.W., Jordan, B.D., Lim, J. and Tan, R., 2012. Fundamentals of Corporate Finance: Asia Global Edition.

Shleifer, A. and Vishny, R.W., 1997. A survey of corporate governance. The journal of finance, 52(2), pp.737-783.

Thanatawee, Y., 2011. Life-cycle theory and free cash flow hypothesis: Evidence from dividend policy in Thailand. International Journal of Financial Research, 2(2).

Turner, J.D., Ye, Q. and Zhan, W., 2013. Why do firms pay dividends?: Evidence from an early and unregulated capital market. Review of Finance, 17(5), pp.1787-1826.

Vo, D.H. and Nguyen, V.T.Y., 2014. Managerial ownership, leverage and dividend policies: Empirical evidence from Vietnam's listed firms. International journal of economics and finance, 6(5), pp.274-284.

Wang, X., Manry, D. and Wandler, S., 2011. The impact of government ownership on dividend policy in China. Advances in Accounting, 27(2), pp.366-372.

Yarram, S.R. and Dollery, B., 2015. Corporate governance and financial policies: influence of board characteristics on the dividend policy of Australian firms. Managerial Finance, 41(3), pp.267-285.

Ye, Z., Zhang, Z. and Tang, S., 2015. Stock dividends policy and liquidity of ex ante announcement: The liquidity hypothesis retest. China Finance Review International, 5(3), pp.258-276.

Yusof, Y., \& Ismail, S. (2016). Determinants of dividend policy of public listed companies in Malaysia. Review of International Business and Strategy, 26(1), 88-99. 